\title{
Hepatitis B Virus Profile among Blood Donors in the Federal Capital Territory Abuja, Nigeria
}

\author{
Agbesor. N. Innocent ${ }^{1}$, Amala Smart E. ${ }^{2}$, Zaccheaus. A. Jeremiah ${ }^{3}$ \\ ${ }^{1}$ Medical Laboratory Unit Department of Medical Services National Assembly Clinic Three Arm Zone, Garki, Abuja \\ ${ }^{2}$ Department of Medical Laboratory Science Rivers State University of Science and Technology Nkpolu, Port Harcourt. \\ ${ }^{3}$ Department of Medical Laboratory Sciences, College of Health Sciences, Niger Delta University, Wilberforce Island, Bayelsa State \\ Nigeria
}

\begin{abstract}
This study was carried out to detect the prevalence of five markers of Hepatitis B virus (HBV) among prospective blood donors between the ages 18-65 years from Asokoro General Hospital Abuja, Nigeria. They were screened for Hepatitis B virus using a rapid stepwise HBV -5 panel immunoassay of Combo Cassette Manufactured by Lusys Laboratories Inc U.S.A. The overall prevalence rates of the five respective markers were: HBsAg 18(17.5), HBeAg 2(1.9), HBsAb 18(17.5), HBeAb 25(24.5), and HBc 63(61.2). Donors aged (30-40) years had the highest prevalence rate of hepatitis $B$ virus infection compared to age group 21-30 years and 41 years and above. Statistically, there was significant relationship between the prevalence rate of $\mathrm{HBs} A \mathrm{~g}$ and frequency of donation at $p(<0.05)$. $A$ strong positive correlation was found to exist between $\mathrm{HBs} \mathrm{Ag}$ and $\mathrm{HBeAg}(r=0.36, p=0.002)$. No correlation was found to exist between HBsAg and other hepatitis $B$ virus markers $(P>0.01)$. Most of the samples that tested negative for HBsAg were found to be positive for other markers especially anti-HBc (IgG and IgM). While anti- HBc IgG is useful for the detection of chronic HBV infection, anti-HBc IgM is useful in detecting recent infection of $\mathrm{HBV}$. Thus, this study has showed that screening for HBsAg alone may not be sufficient for the diagnosis of hepatitis $B$ virus infection.
\end{abstract}

Keywords: Hepatitis B; Blood donors; Serological markers

\section{Introduction}

Hepatitis B virus infection is arguably the most significant global public health problem (barker, 1996; engy, 2011). Of the approximately 2 billion people infected worldwide, 300 million infected patients are chronic carriers of hepatitis $B$ virus (HBV) and it is the $10^{\text {th }}$ leading cause of death (Lavenchy, 2004,). Hepatitis B virus was among the first virus to be transmitted by blood and blood products. HBV infection from transfusion became rare after the introduction of HBsAg in the early 1970, but remains one of the major complications of transfusion particularly in countries with high and intermediate prevalence rate (Durro, 2011). The residue risk of $\mathrm{HBV}$ through transfusion is higher, this is attributed to the interval between initial HBV infection and detection of $\mathrm{HBsAg}$, resulting in a long window phase during which the virus is transmitted (Durro, 2011; Jeremiah, 2011). Development of sensitive assays to detect HBV-DNA shows that healthy HBsAg negative donors who are anti-HBc positive may harbour an occult HBV infection and maintain HBV-DNA sequence in their blood and liver. This present a potential source of HBV transmission. The absence of HBsAg in the blood of apparently healthy individuals may not be sufficient to ensure lack of circulating $\mathrm{HBV}$, thus blood containing anti-HBc with or without detectable presence of HBsAg might be infectious(Japhet, 2011; Jeremiah, 2011). Studies from different parts of Nigeria have reported varying prevalence rate of HBsAg among blood donors, however, information on other markers of HBV is scare, because DNA testing of all collected units is not feasible because of the cost of running the test in Nigeria. This study was therefore conducted primarily to determine the prevalence of other markers of hepatitis B virus and to evaluate the reliability of using HBsAg marker alone in diagnosis of hepatitis B virus infection in screening blood donors in our transfusion centres in Nigeria.

\section{Material and Methods}

\subsection{Subjects}

One hundred and three apparently healthy blood donors were recruited randomly into this cross sectional study between March to June 2012. All the donors were those who came to donate blood in Asokoro General Hospital Abuja, Nigeria. Institutional ethical approval for this study was given by the department of Medical Laboratory Sciences, Rivers State University of Science and Technology, Port Harcourt. All the participants gave their written informed consents before blood samples were collected from them. 5 millilitres of blood was collected through the vein into the EDTA container. The plasma separated through the centrifugation at $1,000 \mathrm{rpm}$ for 5 minutes for Hepatitis B virus antibodies immunoassay techniques testing. Combo Cassette HBV panel immunoassay manufactured by Lusys Laboratories Inc U.S.A were used in a stepwise order for the detection of HBsAg, HBeAg, HBsAb, HBeAb and $\mathrm{HBcAb}$ respectively in the blood. This method which is immunochromatographic and qualitative in nature, detects the presence of five markers of HBV in human blood and can be read in-vitro having more than $99.9 \%$ sensitivity and $99.75 \%$ specificity. The interpretation of test results was performed according to manufacturer's specification.

\subsection{Statistical Analysis}

The data was subjected to statistical analysis using SPSS computer software version 17.0 for windows to determine any significant relationship between infection rate, age, gender and frequency of donation for the different markers 


\section{International Journal of Science and Research (IJSR) \\ ISSN (Online): 2319-7064 \\ Index Copernicus Value (2013): 6.14 | Impact Factor (2015): 6.391}

of HBV. The result of the two tailed probability ( $p$ values). $\mathrm{P}<0.05$.

\section{Results}

Prevalence of HBV markers
Of the 103 blood samples tested HBsAg was detected in $18(17.5 \%)$, HBeAg 2(1.9\%), anti- HBs 18(17.5\%), anti$\mathrm{HBe} 25(24.5 \%)$ and anti-HBc is detected in $63(61.2 \%)$ respectively. The total prevalence of positive and negative markers detected are $24.5 \%$ and $75.5 \%$ respectively as summarized in table 1.

Table 1: The prevalence of HBV markers among blood donors

\begin{tabular}{|l|c|c|c|}
\hline Serological markers & Total Samples & Total positive (\%) & Total negative (\%) \\
\hline HBsAg & 103 & $18(17.5)$ & $85(82.5)$ \\
HBeAg & 103 & $2(1.9)$ & $101(98.1)$ \\
HBsAb & 103 & $18(17.5)$ & $85(82.5)$ \\
$\mathrm{HBeAb}$ & 103 & $25(24.3)$ & $78(75.7)$ \\
$\mathrm{HBcAb}$ & 103 & $63(61.2)$ & $40(38.8)$ \\
\hline
\end{tabular}

Table 2: The Prevalence of HBV Markers among blood donors by gender HBV POSITIVE MARKERS

\begin{tabular}{|l|l|l|l|l|l|l|}
\hline GENDER & $\mathrm{NO}$ & $\mathrm{HBsAg}(\%)$ & $\mathrm{HBeAg}(\%)$ & $\mathrm{HBsAb}(\%)$ & $\mathrm{HBeAb}(\%)$ & HBc (\%) \\
\hline Male & $\mathrm{n}=99$ & $16(16.2)$ & $2(2.0)$ & $17(17.2)$ & $24(24.2)$ & $60(60.6)$ \\
\hline Female & $\mathrm{n}=4$ & $2(50.0)$ & $0(0.0)$ & $1(25.0)$ & $1(25.0)$ & $3(75.0)$ \\
\hline P-value & & 0.140 & 1.000 & 0.542 & 1.000 & 1.000 \\
\hline
\end{tabular}

$\mathrm{Ns}=$ not significant.

Of the 99 males blood donors enrolled for this study, $16(16.2 \%), 2(2.0 \%), 17(17.2 \%), 24(24.2 \%)$, and $60(60.6 \%)$ were positive for $\mathrm{HBsAg}, \mathrm{HBeAg}$, anti-HBs, anti-HBe and anti-HBc respectively. Among the 4 females enrolled for the study, $2(50.0 \%), 0(0.0 \%), 1(25.0 \%)$ and $1(25.0 \%)$ and
$3(75.0 \%)$ were positive for $\mathrm{HBsAg}, \mathrm{HBeAg}$, anti-HBs, ant$\mathrm{HBe}$, anti-HBc respectively (table 2 ). There is no significant difference $(p<0.05)$ between the distribution of $\mathrm{HBV}$ markers among blood donors in relation to gender.

Table 3: Prevalence of HBV Markers among blood donors by age HBV POSITIVE MARKERS

\begin{tabular}{|l|l|l|l|l|l|l|}
\hline AGE(yrs) & NO & HBsAg(\%) & HBeAg(\%) & HBsAb(\%) & HBeAb(\%) & HBcAb(\%) \\
\hline $21-30$ & $\mathrm{n}=48$ & $9(18.8)$ & $1(2.1)$ & $6(12.5)$ & $13(27.1)$ & $29(60.4)$ \\
\hline $31-40$ & $\mathrm{n}=39$ & $8(20.5)$ & $1(2.6)$ & $8(20.5)$ & $8(20.5)$ & $25(64.1)$ \\
\hline $41+$ & $\mathrm{n}=16$ & $1(6.3)$ & $0(0.0)$ & $4(25.0)$ & $3(18.8)$ & $9(56.3)$ \\
\hline P-value & & 0.427 & 0.818 & 0.427 & 0.691 & 0.854 \\
\hline X & & 1.70 & 0.401 & 1.70 & 0.739 & 0.316 \\
\hline
\end{tabular}

Ns $=$ Not significant

Regarding age, HBV markers were significantly higher in age group 31-40 years compared to other age group. The difference in HBV markers for 31-40 years in comparison to other age group in the study was not significant. This is summarized in table 3 .

Table 4: Influence of Frequency of Donation on the Prevalence of HBV Markers HBV POSITIVE MARKERS

\begin{tabular}{|c|c|c|c|c|c|c|}
\hline $\begin{array}{c}\text { Frequency of } \\
\text { donation }\end{array}$ & $\mathrm{NO}$ & HBsAg(\%) & HBeAg(\%) & HBsAb (\%) & HBeAb(\%) & HBcAb(\%) \\
\hline 0 & $\mathrm{n}=44$ & $13(29.5)$ & $1(2.3)$ & $5(11.4)$ & $8(18.2)$ & $24(54.5)$ \\
\hline 1 & $\mathrm{n}=27$ & $1(3.7)$ & $0(0.0)$ & $6(22.2)$ & $7(25.9)$ & $18(66.7)$ \\
\hline 2 & $\mathrm{n}=21$ & $4(19.0)$ & $1(4.8)$ & $5(23.8)$ & $5(23.8)$ & $14(66.7)$ \\
\hline $3+$ & $\mathrm{n}=11$ & $0(0.0)$ & $0(0.0)$ & $2(18.2)$ & $4(36.4)$ & $7(63.6)$ \\
\hline $\mathrm{X} 2$ & & 10.36 & 1.655 & 2.150 & 1.803 & 1.452 \\
\hline P-value & & $0.016^{*}$ & 0.647 & 0.542 & 0.614 & 0.693 \\
\hline
\end{tabular}

$*=$ significant at $\mathrm{p}<0.05$

In relation to frequency of donation, it was found that first time donors had the highest prevalence of HBsAg marker compared to other donors. The frequency of HBV markers decreases as the number of donation increases. All exposed groups showed significant association with HBsAg at $\mathrm{p}<0.05$ as shown in table 4 . 


\section{International Journal of Science and Research (IJSR) ISSN (Online): 2319-7064}

Index Copernicus Value (2013): 6.14 | Impact Factor (2015): 6.391

Table 5: Pearson Correlation Matrix of the Hepatitis B Virus Markers

\begin{tabular}{|c|c|c|c|c|c|}
\hline Parameter & & HBsAg & $\mathrm{HBeAg}$ & HBsAb & $\mathrm{HBeAb}$ \\
\hline \multirow[t]{2}{*}{$\mathrm{HBeAg}$} & $\mathrm{R}$ & .306 & & & \\
\hline & p-value & $.002 * *$ & & & \\
\hline \multirow[t]{2}{*}{$\mathrm{HBsAb}$} & $\mathrm{R}$ & -.144 & -.065 & & \\
\hline & P-value & .145 & .516 & . & \\
\hline \multirow[t]{2}{*}{$\mathrm{HbeAb}$} & $\mathrm{R}$ & .049 & -.078 & -.072 & \\
\hline & P-value & .625 & .436 & .468 & \\
\hline \multirow[t]{2}{*}{$\mathrm{HBcAb}$} & $\mathrm{R}$ & .052 & -.032 & -.001 & .156 \\
\hline & P-value & .602 & .746 & .996 & .115 \\
\hline
\end{tabular}

There is strong positive correlation between HBsAg and $\mathrm{HBeAg}$ at $\mathrm{r}=0.306$ and $\mathrm{p}=0.002$ while $\mathrm{HBsAg}$ has no significant correlation with other HBV markers. (table5).

\section{Discussion}

Out of the 103 blood samples tested, HBsAg was detected in 18(17.5\%) HBeAg 2(1.9\%), anti HBsAb 18(17.5\%), anti$\mathrm{HBeAb} 25(24.3 \%)$ and anti-HBc Ab 61.2\% respectively.

Gender-specific difference showed that female blood donors had higher seropositivty for the five markers than the male counterpart, however there was no significant different ( $\mathrm{p}>$ 0.05 ). The reason for this difference might be due to large number of male blood donors in this study than the females. This observation contradict what had been previously reported by some authors,( Mehmet, 2005) in his study reported higher prevalence rate in male than females in both rural and urban, with the observation that male sex is an important factor for HBV positivity. The same high prevalence rate of $\mathrm{HBsAg}$ was reported among males than the females in Lagos, Nigeria (Balogun , 2010). A similar study also reported a higher HBsAg prevalence in males than females among patients attending dental Clinic, University College Hospital, Ibadan, Nigeria, this was due to shorter carrier HBsAg rate in female than the males (Olubuyide,2007, Ola, 2004, Lawal, 2009). However, the observation in this study is comparable to a report by (Uneke, 2005), which state that females are more infected with HBsAg than the male. Another reason for the high infection rate among females may be due to habit such as multiple sexual partnership (Lawal, 2009). The lack of statistical difference in HBV markers suggests that they were equally exposed to $\mathrm{HBV}$ in corroboration with earlier findings (Agbede, 2007, Ugwuja and Ugwu, 2010).

Blood donors within the age group (31-40) years had the highest prevalence of HBV markers than (21-30) years and 41 years above as shown in table 2 . This study support the earlier report with high prevalence of HBV in older subjects 40 years and above than in younger people (Lawal, 2009, Okonko, 2012).Also, Luka et al,(2008) in their study, reported higher HBV prevalence among older age group (30-34)years. The finding in this study contradict Buseri et'al (2009), who noted that HBV infection are more prevalent in younger subjects within ages 21-29 years, the possible reason for this high prevalence rate in older people than younger people may be attributed to their active sexual activities and drug abuse, however, we observed that HBV is not limited to any particular age group.
Out of the 103 blood donors as shown in table 4; 44(42.7\%) samples were collected from first time donors, 27 (26.2\%), second time donors, third and fourth time donor were $21(20.4 \%)$ and $11(10.7 \%)$ respectively. The prevalence of HBV markers was high among the first time donors than repeat donors and repeat donors are safest (Kanchan, 2013). This result is in agreement with previous study conducted among blood donors at Gondar University Teaching Hospital, Northwest Ethiopia (Tessema, 2010). This shows that HBV infection decreases as the frequency of donation increases. The possible reason is that the more an individual donates blood the more the donor becomes enlightened. There is statistical difference in $\mathrm{HBsAg}$ associated with frequency of donation at $(\mathrm{p}<0.05)$.

The result of this study showed that $63(61.2 \%)$ blood donors had anti-HBc as the only serological markers. This finding agrees with earlier report that testing blood donors for $\mathrm{HBsAg}$ alone is not sufficient to eliminate HBV from supply Geraldine, 2006; Chaudhiri, 2006 observed the presence of HBV-DNA in one fifth of anti-HBc only positive donors studied and stated that, reactivity to anti $\mathrm{HBc}$ only can predict cryptic HBV infection. It is possible that some of the blood donors are in their window period and may have $\mathrm{HBc}$ IgM antigen at the stage when HBsAg is not detectable in the blood. The only serologic evidence of infection with hepatitis B infection is the presence of $\operatorname{IgM}$ antibody to the core antigen. Blood from this anti-HBc only donors might have been transfused to innocent patients since the donors tested negative due to undetectable HBsAg in their blood thereby increasing the number of transmissible HBV. The screening test for detection of HBsAg does not rule out the transmission of Hepatitis B as the donors might be in the window period and detection of the antibody to hepatitis $\mathrm{B}$ core antigen ( $\mathrm{HBc} \operatorname{IgM}$ ) type serves as a useful serological markers during window period. A prevalence of $61.2 \%$ observed for anti-HBc in this study is high compared with $0.56 \%$ in the united kingdom (Soldan ,1999), $0.84 \%$ in the United State (Kleinman, 2000), 1.13\% in Canadian blood donors (O’Bran ,2007), 4.85\% in Italy (Paola, 2007).

In areas of high HBV infection, prevalence rate is about 20$70 \%$ positive for anti-HBc. The result from this study showed high anti-HBc prevalence compared to those obtained in Indian 18.9\%, Pakistan 17.28\% and Turkey 20.0\% (Duygu,2007), 18.1\% in Maiduguri, Borno State, Nigeria (Jeremiah, 2011) but lower than $76.0 \%$ in Ghana(Allain , 2003). IgM class of the anti-HBc is a marker that indicates recent infection, $\mathrm{IgG}$ variety of anti $\mathrm{HBc}$ appears later during the infection and points to a past $\mathrm{HBV}$ infection. In this study, the anti-HBc only is $63(61.2 \%)$ which is comparable to $60.9 \%$ reported by ( Akinbami ,2012). Anti $\mathrm{HBc}$ IgG may remain positive for life in an infected individual, although the individual has protective levels of anti HBs, the blood of such a donor might be free from transmitting HBV (Van Ditzhiyisen, 2010). Strong positive correlation was found to exist between HBsAg and $\mathrm{HBeAg}(\mathrm{r}=0.306$ and $\mathrm{p}=0.002)$. No correlation was found to exist between HBsAg and HBV markers as shown in table 5. 


\section{International Journal of Science and Research (IJSR) \\ ISSN (Online): 2319-7064}

Index Copernicus Value (2013): 6.14 | Impact Factor (2015): 6.391

\section{Conclusion}

This study showed an overall prevalence rate of HBsAg to be $17.5 \%$, HBeAg $1.9 \%$, anti-HBc $63(61.2 \%)$, among prospective blood donors in Abuja, Nigeria. This study however, confirmed the presence of HBV markers among apparently healthy blood donors. Majority of them might have acquired the infection through sex and blood transfusion during window period or late phase chronic HBV, when HBsAg is at undetectable level. Thus the need for inclusion of $\mathrm{HBc}$ in routine screening of blood donors in Nigeria is necessary to reduce risk of transfusing $\mathrm{HBV}$ infection.

\section{References}

[1] Barker L.F. (1996). "Transmission of serum hepatitis B 1970" Journal of American Medical Association. 276 (10), 841-844.

[2] Engy Y.E.A(2011). Overview on Hepatitis B virus. Nature and Science, (9) 3, 31-36.

[3] Levanchy D.(2004). Hepatitis B virus Epidemiology, Disease Burden, Treatment, and Current and Emerging prevention and control measures. Journal of Viral Hepatology. 11(2), 97-107.

[4] Durro V, Onyra S (2011). Trend in the prevalence of hepatitis B virus infection among Albanian blood donors. Virology Journal. (8),96.

[5] Jeremiah Z.A, Idris H, Ajayi B.B, Ezimah A.C.U, Malah M.B, and Baba M.M (2011). Isolated anti-HBcIgM antibody among blood donors in semi-arid region of Nigeria. Human antibodies, 20, 77-82.

[6] Japhet M.O, Adesina O.A, Donbraye E, and Adewumi M.(2011). Hepatitis B core IgM antibody (antiHBcIgM) among hepatitis B surface (HBsAg) negative blood donors in Nigeria.Virology Journal. 8, 513

[7] Mehmet D, Meliksah E, Serif Y, Gunay S, Tuncar O, Zeynep S, (2005). Prevalence of Hepatitis B infection in the Southeastern region of Turkey: Comparison of risk factors for HBV infection in rural and urban areas. Journal of Infectious Disease, 58: 15-19.

[8] Balogun T.M, Durojaiye I.O, Sagoe A, Emmanuel S. (2010). Seroepidemiology of Hepatitis B surface Antigaemia in HIVpositve patients. West African Journal of Medicine. 29(3): 167-173.

[9] Olabuyide I.O, Ola S.O, Aliyu B, Dosumu O.O, and Arotiba J.T.(1997). Hepatitis B and C in doctors in Nigeria. Nigerian Ouarterly Journal of Medicine. 90: 417-422.

[10] Ola S.O, Odaibo G.N, Olaleye D.O. (2004). HCV and HBV infections in Nigerian patients with liver cirrhosis and hepatocellular carcinoma. Nigerian Ouarterly Journal of Medicine. 14:3-4..

[11] Lawal O.A, Bakarey A.S, Uche L.N, Udeze A.O Okonko I.O. (2009). HBV infection among intending blood donors who incidentally tested positive to HIV antibodies in two blood banks in Ibadan, Nigeria. World Applied Science Journal,11(2), 97-107.

[12] Uneke C.J, Ogbu P.U.I, Anyanwu G.I, Njoku M.O, and Idoko J.H.(2005). Prevalence of hepatitis B surface antigen among blood donors and HIV-infected patients in Jos, Nigeria. Memorias do Instituto Oswaldo Cruz Rio de Janerio, 100 (1),13-16
[13] Agbede O.O, Iseniji O.J, Kolawole M.O and Ojuawo A.(2007). A risk factors and prevalence of hepatitis B surface antigenaemia in mothers and pre-school age children in Nigeria. Therapy, 4(1), 67-72.

[14] Ugwuja E, and Ugwu N.(2010). Seroprevalence of Hepatitis Bsurface Antigen and Liver Function Tests among Adolescents in Abakaliki, South Eastern Nigeria. The Internet Journal of Tropical Medicine,6(1) 5580-297.

[15] Okonko O.I and Udeze A.O (2011). Detection of hepatitis B surface Antigen (HBsAg) among pregnant women attending Antenatal Clinic at O.L.A Catholic Hospital, Oluyoro, Ibadan, Oyo State, Southwestern. Nature and Science; 9(11): 54-60.

[16]Luka S.A, Ibrahim M.B and IIiya S.N. (2008). Seroprevalence of hepatitis Bsurface antigen among pregnant women attending Ahmadu Bello University Teaching Hospital, Zaria, Nigeria. Nigerian Journal of Parasitology, 29(1): 38-41.

[17] Buseri F.I, Muhibi M.A and Jeremiah Z.A,(2009). Seroepidemiology of transfusion transmissible infection diseases among blood donors in Osogbo, South West Nigeria. Blood Transfusion, 7(4), 293-299.

[18] Kanchan B, Prasad K.M, Ravisha B, and Bhardwaj B.L (2013). Seroprevalence of HBsAg and HCV in healthy blood donors at a tertiary Care Hospital in India. Research Journal of Pharmaceutical, Biological, and Chemical Vol 4(4): 1272-1278.

[19] Tessema B, Yismaw G, Kassu A, Amsalu A, Sack U(2010). Seroprevalence of HIV, HBV, HCV and Syphilis infections among blood donors at Gondar University Teaching Hospital Northwest Ethiopia: decling trend over a period of five years. Biomedical Central Infectious Diseases 10: 111-117.

[20] Geraldine K, Adel A, Intesar A, Jameel N, Said H.(2006). Evidence of of Ocuult Hepatitis B infection among Omani blood donors: A Preliminary Study. Medical principles and Practice, 15, 368-372.

[21] Chaudhuri V, Nanu A, Panda S.K, Chand P.(2006). Evaluation of serologic screening for blood donors in India reveals a lack of correlation between anti $\mathrm{HBc}$ titre and PCR amplified HBV-DNA. Transfusion 43(100):1442-1448.

[22] Soldan K, Ramsay M, Collins M.(1999). Acute hepatitis $\mathrm{B}$ infection associated with blood transfusion in England and Wales. Biomedical Journal. 318(7176):95

[23] Kleinman S.H, Busch M.P .(2000). The risks of transfusion transmitted infection :direct estimation and mathematical modelling. Baillieres Clinical Haematology, 13(4), 631-49.

[24] O’Brien S.F, Fearon M.A, Yi Q.L, Fan W, Scalia V, Muntz I,R.(2007). Hepatitis B virus DNA-positive, hepatitis $\mathrm{B}$ surface antigen negative blood donations intercepted by anti-hepatitis B core antigen testing: Canadian blood experience. Transfusion 47, 1809-15.

[25] Paola M, Mauro G, Raffaele B, Osvaldo G, Roberto G, Maurizio L.(2007).Italian blood donors with anti-HBc and occult hepatitis B virus infection. Haematological, 92(12), 1664-1670).

[26] Dugyu F, Ugur A, Mahmut B. (2007). Determination of hepatitis B virus DNA incidence, viral load, and mutation in blood donors with HBsAg and anti-HBsnegative serology and antibodies to hepatitis B core 


\section{International Journal of Science and Research (IJSR) \\ ISSN (Online): 2319-7064}

Index Copernicus Value (2013): 6.14 | Impact Factor (2015): 6.391

antigen. European Journal of Internal Medicine, 18, 571-575.

[27] Allain J.P. (2004). Occult hepatitis B virus infection: Implication in Transfusion. Vox Sangiunis, 86, 83-91.

[28] Akinbami A.A, Oshinaike O.O, Adediran A, Akpanmu S, Wright K.O, IIori S, and Alle K.(2012). Seroprevalence of Hepatitis $\mathrm{Be}$ antigen (HBe antigen) and HBcore antibodies (IgG anti-HBcore and IgM antiHBcore) among hepatitis B surface antigen positive blood donors at a tertiary health centre in Nigeria. Biomedical Clinical Research Notes. 5, 167.

[29] Van Ditzhuijsen T.J.M, Selten G.C.M, Van Loon A.M, Woiters G,Matthyseen L, and Yap S.H (2005). Detection of Hepatitis B virus DNA in serum and in relation with $\operatorname{IgM}$ class anti-HBc titre in Hepatitis B virus Infection. Journal of Medical Virology, 15, 49-56.

Volume 5 Issue 7, July 2016 www.ijsr.net 